\title{
ANALISIS CITRAAN PENGLIHATAN \\ DALAM ANTOLOGI PUISI DI HADAPAN RAHASIA \\ KARYA ADIMAS IMMANUEL
}

\author{
Leni Patmawati ${ }^{1}$, Sumiharti $^{2}$, Sujoko $^{3}$ \\ Program Studi Pendidikan Bahasa dan Sastra Indonesia, \\ Fakultas Keguruan dan Ilmu Pendidikan, Universitas Batanghari, \\ Jambi \\ lenifatmawati1994@gmail.com \\ harti.sumi@yahoo.com \\ sujoko1987@yahoo.com
}

\begin{abstract}
This research is intended to decribe imagery that is found in Poetry Anthology $D i$ Hadapan Rahasia by Adimas Immanuel. The method of this research is descriptive by using content analysis. The sourec of the data is pramary and secondary data. In this research, the primary data is taken from the sequence of beutiful words that have a meaning and visual imagery in their every linein Poetry Anthology in Di Hadapan Rahasia by Adimas Immanuel. The secondary data is taken from books and literature. Based on the result of the research, it can be concluded that there are 30 imagery in the poetry written by Adimas Immanuel. The types of the imagery is follows: (1) 4 visual imagery. Thus, imagery is one of the way that can be used in identifying a poetry.
\end{abstract}

Key words: imagery,poetryi,poetry anthology

\footnotetext{
${ }^{1}$ Mahasiswa Program Studi Pendidikan Bahasa dan Sastra Indonesia, Fakultas Keguruan dan Ilmu Pendidikan, Universitas Batanghari, Jambi

${ }^{2}$ Dosen Program Studi Pendidikan Bahasa dan Sastra Indonesia, Fakultas Keguruan dan Ilmu Pendidikan, Universitas Batanghari, Jambi

${ }^{3}$ Dosen Program Studi Pendidikan Bahasa dan Sastra Indonesia, Fakultas Keguruan dan Ilmu Pendidikan, Universitas Batanghari, Jambi 


\section{PENDAHULUAN}

Puisi merupakan jenis karya sastra yang diciptakan menggunakan bahasa yang khas, dengan memperhatikan gaya, makna, dan lainnya sehingga karya tersebut dapat dinikmati oleh pembacanya. Puisi merupakan ungkapan keluh kesah terhadap hal-hal yang dialami oleh pengarang. Puisi dijadikan pengarang sebagai media untuk mencurahkan semua hal yang dirasakannya. Puisi biasanya akan bermakna apabila puisi tersebut memiliki keindahan yang diciptakan oleh penulisnya dan dapat diterima oleh pembacanya, diterima dalam artian dapat dimegerti maksud dan tujuannya.

Puisi adalah salah satu karya sastra yang sulit untuk dipahami. Hal inilah yang menghadirkan momok dikalangan penikmat sastra menjadi kurang menggemari puisi. Sehingga jika dibandingkan antara puisi dan karya sastra lainnya seperti cerpen dan novel, maka para pembaca lebih cenderung gemar membaca novel dibandingkan dengan puisi.

Sejauh pengamatan penulis, selama PPL (Praktik Pengalaman Lapangan) di SMK Negeri 1 Kota Jambi hanya sedikit siswa yang berminat dalam membaca puisi. Dengan berbagai keterbatasan pengetahuan siswa terhadap puisi, maka pemahaman siswa terhadap puisi pun akan didapat seadanya Fenomena inilah yang menurut peneliti penting bahwa penelitian terhadap puisi ini perlu dilakukan. Karena melalui penelitian ini, peneliti akan menunjukkan bagaimana memahami puisi melalui satu sudut pandang yang dianggap peneliti sebagai acuan dalam penafsiran puisi tersebut sehingga melahirkan pemahaman terhadap makna tersirat dari puisi-puisi yang diteliti. Untuk itu sebagai bahan analisis penulis memilih puisi yang ada pada antologi puisi Di Hadapan Rahasia karya Adimas Immanuel.

\section{Antologi puisi Di Hadapan} Rahasia adalah karya Adimas Immanuel. Puisi Di Hadapan Rahasia diluncurkan di Taman Ismail Marzuki, Jakarta Pusat, hari Rabu, 17 Februari 2016. Antologipuisi Di Hadapan Rahasia Karya Adimas Immanuel diterbitkan oleh Gramedia Pustama Utama. Kegiatan peluncuran buku ini, dikemas dengan resital piano yang dibawakan oleh maestro piano Ananda Sukarlan, dan juga menggandeng penyanyi Sopran Mariska Setiawan untuk menyanyikan lima puisi Adimas yang ada dalam buku $D i$ 
Hadapan Rahasia. Kelima puisi itu adalah Sakal, Menanam Rahasia, Prahabitat, DiHadapan Rahasia, dan Iras,

(http://www.entertainment.kompas.com/r ead/2016/02/18/134109910/.Di.Hadapan. Rahasia.Adimas.Immnuel.Gandeng.Anan da.Sukarlan.html,diakse11 November 2016).

Alasan penulis memilih antologi puisi Di Hadapan Rahasia karya Adimas Immanuel ini karena Adimas Immanuel adalah seorang mahasiswa berprestasi yang meluncurkan puisi sebanyak 70 buah puisi sekaligus, sehingga membuat penulis terinspirasi olehnya dan tertarik untuk menganalisisnya. Selain itu, kumpulan puisi ini mempunyai keunikan tersendiri tidak seperti kumpulan puisi lainnya, karena pemilihan diksi di dalamnya begitu cermat sehingga melahirkan kata-kata yang indah, membuat pembaca hanyut dalam imajinasinya. Puisi mempunyai unsur pembangun yang berupa unsur intrinsik dan unsur ekstrinsik. Unsur ekstrinsik merupakan unsur pembangun puisi dari salah astunya berupa citraan.

Di dalam puisi, Citraan merupakan salah satu cara memanfaatkan bahasa. Pemanfaatan citraan secara baik dan tepat menciptakan suasana kepuitisan. Ada beberapa penyair yang menyandarkan kekuatan puisinya pada faktor citraan. Citraan memberikan kemudahan untuk memahami puisi sekaligus merupakan gaya untuk memperindah penuturan, begitu juga dalam menulis puisi, penyair bebas menggunakan bahasa yang indah dan gambaran-gambaran angan (imaji) sebagai alat kepuitisannya.

Diksi dalam puisi erat hubungannya dengan citraan. Citraan menggambarkan kesan atau bayangan visual yang timbul dari sebuah kata, kelompok kata, atau kalimat yang merupakan unsur dasar yang khas dalam puisi. Belum tercapainya pemahaman peneliti secara menyeluruh dan mendalam dalam menelaah karya sastra puisi, hal ini membuat peneliti tertarik untuk mengetahui adanya salah satu nilai kepuitisan dalam puisi yaitu citraan yang dapat membangkitkan tanggapan imajinasi pembaca dalam membaca atau menikmati puisi.

Berdasarkan penjelasan di atas, penulis memilih citraan untuk dianalisis dalam antologi puisi $D i$ Hadapan Rahasia karya Adimas Immanuel karena citraan merupakan salah satu gaya penuturan yang banyak dimanfaatkan dalam penuliasan karya sastra khususnya pada puisi. Berdasarkan urain di atas, identifikasi masalah dalam penelitian ini 
adalah bagaimanakah citraan penglihatan dalam antologi puisi Di Hadapan

Rahasia karya Adimas Immanuel?

Tujuan penelitian ini adalah untuk mendeskripsikan citraan penglihatan dalam Antologi Puisi Di Hadapan Rahasia Karya Adimas Immanuel.

Secara teoretis teori-teori dalam penelitian ini diharapkan: 1) dapat memperkaya khazanah ilmu pengetahuan bahasa Indonesia dan memberikan sumbangan ide bagi penelitian lain, khususnya pada bidang kajian sastra; 2) untuk mengembangkan pengetahuan teori kesastraan dan sebagai sumbangan informasi mengenai unsur citraan; 3) sebagai dasar penelitian lebih lanjut di masa mendatang dan dapat memberi rujukan untuk penelitian selanjutnya.

Secara praktis penelitian ini diharapkan dapat bermanfaat bagi berbagai pihak, diantaranya yaitu : 1) sumber pengetahuan tambahan bagi pembaca dan bagi peneliti sastra; 2) meningkatkan apresiasi masyarakat terhadap karya sastra yang berbentuk puisi; 3) mempermudah dalam memahami karya sastra terutama puisi dalam Antologi Puisi Di Hadapan Rahasia Karya Adimas Immanuel; 4) sebagai acuan pembaca untuk memahami unsur pencitraan dalam suatu karya sastra khususnya puisi; 5) sebagai penerapan ilmu pengetahuan bagi penulis.

\section{METODE PENELITIAN}

Metode penelitian pada dasarnya merupakan cara ilmiah untuk mendapatkan data dengan tujuan dan kegunaan tertentu. Metode penelitian dapat menentukan keberhasilan sebuah penelitian. "Metode penelitian sastra adalah cara yang dipilih oleh peneliti dengan mempertimbangkan bentuk, isi, dan sifat sastra sebagai subjek kajian" (Endraswara, 2003:8). Melalui penelitian, seorang peneliti sastra dapat memilih cara untuk menafsirkan kekaburan dalam suatu karya sastra sehingga karya sastra tampak jelas.

"Metode merupakan cara yang dipergunakan seorang peneliti didalam usaha memecahkan masalah yang diteliti. Oleh sebab penelitian merupakan kegiatan ilmiah, metode harus sistematis atau prosedural" (Siswantoro, 2010:55). Metode harus sistematis atau prosedural, sitematis artinya seorang peneliti harus bekerja secara teratur di dalam upaya memecahkan masalah dan tidak bisa bergerak dari satu aspek ke aspek lain. Gerakan atau cara berfikir harus tetap terjalin antara aspek yang satu dengan aspek lain secara terpadu (solid). 
Metode yang digunakan dalam penelitian ini adalah metode deskriptif kualitatif, yaitu metode yang mengutamakan kedalaman penghayatan terhadap interaksi konsep yang sedang dikaji secara empiris. "Metode deskriptif dapat diartikan sebagai prosedur pemecahan masalah yang diselidiki dengan menggambarkan atau melukiskan keadaan subjek atau objek penelitian pada saat sekarang berdasarkan faktafakta yang tampak atau sebagaimana adanya" (Nawawi dalam Siswantoro, 2010:56). Dengan metode deskriptif, seorang peneliti dituntut untuk memecahkan data dengan cara deskripsikan data yang ada.

\section{HASIL DAN PEMBAHASAN}

Setelah melakukan analisis terhadap 17 buah puisi dalam antologi puisi Di Hadapan Rahasia karya Adimas Immanuel, terdapat 4 citraan penglihatan. Maka dapat diketahui puisi yang mengandung citraan penglihatan berjumlah empat puisi di antabahwa ranya puisi yang berjudul Iras, Anopsia, Sontrot, dan Sepeda Tua, untuk lebih jelas pembahasan tentang empat jenis citraan tersebut dalam antologi puisi Di Hadapan Rahasia karya Adimas Immanuel dijelaskan sebagai berikut.
Citraan penglihatan (visual imagery) adalah citraan yang timbul oleh penglihatan. Citraan ini memberikan rangsangan kepada indera penglihatan, sehingga hal-hal yang tak terlihat seolaholah terlihat. Dalam antologi puisi $D i$ Hadapan Rahasia citraan penglihatan dapat dilihat dalam kutipan berikut:

1) Seperti tebing batu di kanan-kirimu, begitulah pandangan-pandangan yang menjatuhkan itu. (Iras, hlm.18)

Kutipan (1) puisi Iras, diksi seperti tebing batu di kanan-kirimu, begitulah pandangan-pandangan yang menjatuhkan itu dihadirkan penyair pada kutipan puisi diatas mampu menggugah indera penglihatan pembaca untuk membayangkan keadaan seseorang yang sedang berada diketinggian yang seolaholah melihat tebing di sisi kanan dan kirinya yang begitu menakutkan.

2) $\ldots$

Wajah yang menoleh, melihat mayat kaku membujur, ditumbuhi ngilu menyemak sulur. Wajah yang saksikan kelahiran bayi kelelawar, yang merah, seperti mata anjing hutan, anjing bayangan, dengan bulu sepekat nanah, melayak sepanjang hari, hingga hasrat berhenti, menyalakan ketakukatan di jalan penghabisan ini.

(Anopsia, hlm.24) 
Kutipan (2) puisi Anopsia, diksi

Wajah yang menoleh, melihat mayat kaku membujur, ditumbuhi ngilu menyemak sulur. Wajah yang saksikan kelahiran bayikelalawar, yang merah, seperti mata anjing hutan, anjing bayangan, dengan bulu sepekat nanah, melayak sepanjang hari, mampu menggugah indera penglihatan pembaca untuk melihat mayat yang telah kaku membujur yang begitu menakutkan. Menyaksikan bayi kelelawar yang baru dilahirkan berwarna merah, matanya seperti anjing hutan dengan bulu yang berlumur darah dan merengek sepanjang hari.

3) Kau bercerita pohon poplar agung batangnya danwarna kelopak peoni mendamaikan mata.

(Sontrot, hlm.37)

Kutipan (3) puisi Sontrot, diksi pohonpoplar agung batangnya dan warna kelopak peoni mendamaikan mata. Mampu menggugah indera penglihatan pembaca untuk menceritakan pengalaman penyair, dimana penyair sedang menikmati keindahan pohon poplar yang begitu agung batangnya dan kelopak peori begitu indah hingga melihatnya dapat mendamaikan mata.

4) Duduklah di belakang. Duduklah meski bantalnya tak empuk benar. Duduklah sambil menikmati guguran daun, sejuk embun pagi hari, tetangga

yang masih saling menyapa, dan sejumlah wajah yang kita lihat sepintas dan tak akan kita jumpai lagi. (Sepeda Tua, hlm. 64)

Kutipan (4) puisi Sepeda Tua, diksi Duduklah sambil menikmati guguran daun, menyatakan bahwa seseorang yang yang sedang bersepeda lalu meminta orang lain agar duduk di belakangnya meski bantal sepeda itu tidak lah empuk untuk menikmati indahnya guguran daun di pagi hari.

\section{SIMPULAN}

Berdasarkan pemaparan hasil penelitian dan pembahasan, dapat disimpulkan dari 17 puisi Adimas Immanuel, peneliti menemukan 4 citraan penglihatan. Jenis-jenis citraan yang terdapat dalam Antalogi Puisi $D i$ Hadapan Rahasia Karya Adimas Immanuel adalah sebangai berikut: citraan penglihatan (visual imagery) berjumlah 4 citraan. Puisi yang terangkum dalam antologi puisi $D i$ Hadapan Rahasia karya Adimas Immanuel menampilkan kata-kata yang indah, menarik dan mampu menggugah imajinasi pembaca khususnya pada citraan pendengaran karena penyair banyak menggunakan daya komunikasinya melalui daya bayang yaitu pendengaran segenap inderanya 
turut merasakan secara langsung

peristiwa yang dialami oleh penyair.

DAFTAR PUSTAKA

Endraswara, Suwardi. (2003).

Metodologi Penelitian Sastra.

Yogyakarta: Caps.
Siswantoro. (2010). Metode Penelitian

Sastra. Yogyakarta: Pustaka Pelajar.

(http://www.entertainment.kompas.com/r ead/2016/02/18/134109910/.Di.H adapan.Rahasia.Adimas.Immnuel. Gandeng.Ananda.Sukarlan.html. 